\title{
Evaluation of Graphite and Metals Separation by Flotation in Recycling of Li-Ion Batteries ${ }^{\dagger}$
}

\author{
Xiaosheng Yang * ${ }^{\mathbb{D}}$, Akseli Torppa and Kimmo Kärenlampi
}

\author{
GTK Mintec, Tutkijankatu 1, 83500 Outokumpu, Finland; akseli.torppa@gtk.fi (A.T.); \\ kimmo.karenlampi@gtk.fi (K.K.) \\ * Correspondence: jason.yang@gtk.fi \\ + Presented at International Conference on Raw Materials and Circular Economy, Athens, Greece, \\ 5-9 September 2021.
}

check for

updates

Citation: Yang, X.; Torppa, A.; Kärenlampi, K. Evaluation of Graphite and Metals Separation by Flotation in Recycling of Li-Ion Batteries. Mater. Proc. 2021, 5, 30. https://doi.org/10.3390/materproc 2021005030

Academic Editor: Anthimos Xenidis

Published: 26 November 2021

Publisher's Note: MDPI stays neutral with regard to jurisdictional claims in published maps and institutional affiliations.

Copyright: (c) 2021 by the authors. Licensee MDPI, Basel, Switzerland. This article is an open access article distributed under the terms and conditions of the Creative Commons Attribution (CC BY) license (https:// creativecommons.org/licenses/by/ $4.0 /)$.

\begin{abstract}
The separation of graphite from cathode active materials containing $\mathrm{Co}, \mathrm{Ni}$, and $\mathrm{Mn}$, and the metals $\mathrm{Cu}$ and $\mathrm{Al}$ by flotation was tested and evaluated with a black mass sample of crushed spent Li-ion batteries. The metals, $\mathrm{Cu}$ and $\mathrm{Al}$, were mostly (>90\%) concentrated by sieving into an oversize fraction $(+0.25 \mathrm{~mm})$. Graphite and the cathode active materials in the oversize fraction $(+0.25 \mathrm{~mm})$ were effectively separated from the metals, $\mathrm{Cu}$ and $\mathrm{Al}$, by flotation. Pre-treatment by roasting at a temperature of $350-450{ }^{\circ} \mathrm{C}$ improved the flotation efficiency of graphite from the cathode active materials for the undersize fraction $(-0.25 \mathrm{~mm})$.
\end{abstract}

Keywords: Li-ion battery; black mass; graphite; flotation; roasting

\section{Introduction}

The global lithium-ion battery (LIB) market is expected to continue to grow, owing to the growing interest of consumers for electric vehicles at a compound annual growth rate (CAGR) of $15 \%$ from 2020 to 2026 [1,2]. The use of LIBs has led to an increase in the amount of spent batteries. However, the estimated recycling rates reported have still been very low [2,3]. In Europe, for example, a total of 65,500 tons of the LIB was consumed between 2013 and 2014, but only about 1900 tons were recycled in the same period [2]. Currently, only the metals $\mathrm{Co}, \mathrm{Ni}$ and $\mathrm{Mn}$, with high economic values which are contained in the cathode active materials, are the main targets for most emerging recycling processes by pyro-hydrometallurgical techniques, and $\mathrm{Li}$ is mainly recovered as part of the cathode active materials. The metals, $\mathrm{Cu}, \mathrm{Al}$ and $\mathrm{Fe}$, are mostly recovered through mechanical and physical processing operations such as magnetic separation. Graphite is presently not of major interest for the battery recycling industry and is mostly lost in the recycling process [2,3]. From a circular economy perspective, recycling graphite is worth considering. Meanwhile, the separation of graphite could promote the efficiency of subsequent metal recovery. Graphite recovery from a mixture of shredded anode and cathodes via selective flotation after thermal or chemical treatment has been studied or patented [4-8]. In the black mass (BM) material, both graphite and Li-containing metal oxides display very good floatability because their surfaces are coated with organic binders such as polyvinylidene fluoride (PVDF). Thus, direct flotation of the BM material showed poor selectivity between graphite and $\mathrm{Ni}, \mathrm{Co}$, and $\mathrm{Mn}$. Thermal treatment by pyrolysis or roasting has proved to be an effective approach for the removal of organic binder's coatings prior to flotation.

In this study, based on the BM material of a recycling process, the separation efficiencies of graphite from the cathode active materials containing $\mathrm{Co}_{0} \mathrm{Ni}$, and $\mathrm{Mn}$, and the metals $\mathrm{Cu}$ and $\mathrm{Al}$ via flotation was evaluated. The effects of roasting as pre-treatment at a temperature of $350-450{ }^{\circ} \mathrm{C}$ on the flotation efficiency of graphite were investigated. 


\section{Materials and Methods}

The black mass (BM) material of spent Li-ion batteries used in this study was sourced from a recycling facility, where the NMC (Ni-Mn-Co) batteries were treated first by shredding and then the shredded material was sieved. The BM material was the undersize $(<\sim 2 \mathrm{~mm})$ fraction of the sieving operation.

A sample of BM weighing about $50 \mathrm{~kg}$ was split into subsamples of $500 \mathrm{~g}$ each for chemical and mineralogical analyses and beneficiation test work.

A subsample of $500 \mathrm{~g}$ was sieved into the fractions of $+1.0 \mathrm{~mm},-1.0+0.5 \mathrm{~mm},-0.5+$ $0.25 \mathrm{~mm},-0.25+0.15 \mathrm{~mm},-0.15+0.106 \mathrm{~mm},-0.106+0.075 \mathrm{~mm},-0.075+0.045 \mathrm{~mm}$ and $-0.045 \mathrm{~mm}$ and separately analysed by XRF for chemical compositions including $\mathrm{Si}, \mathrm{Fe}$, $\mathrm{Mn}, \mathrm{P}, \mathrm{Cu}, \mathrm{Ni}$, $\mathrm{Co}$ and $\mathrm{Al}$, etc. The contents of carbon in the fractions were determined by Leco carbon analysis.

The compositions of compound phases, including graphite, the cathode active materials and metals $\mathrm{Cu}$ and $\mathrm{Al}$, and textural characterization, were measured by the mineral liberation analysis (MLA) using an FEI QUANTA 650 FEG-SEM MLA instrument with two BRUKER XFLASF EDS-detectors. The mineralogical analysis was conducted for two fractions of $-0.25+0.106 \mathrm{~mm}$ and $-0.106 \mathrm{~mm}$ of the BM sample.

The $500 \mathrm{~g}$ subsamples were classified by sieving into two fractions of $+0.25 \mathrm{~mm}$ and $-0.25 \mathrm{~mm}$ as the feeds for flotation. Flotation trials on a laboratory flotation machine with a $1.5 \mathrm{~L}$ cell were carried out. Kerosene was used as the collector for graphite and Dowfroth 250 was added as the frother as needed. Roasting, as pre-treatment prior to flotation, was conducted with a laboratory muffle furnace at a temperature of 350 to $450{ }^{\circ} \mathrm{C}$ for a duration of $30 \mathrm{~min}$.

\section{Results}

\subsection{Particles Size and Elemental Distributions}

\subsubsection{Particle Size Distribution}

The particle size distribution of the BM material was obtained by sieving. Figure 1 showed that about $60 \%$ mass in the material was in $+0.25 \mathrm{~mm}$ fraction and the masses in the $+0.75 \mathrm{~mm}$ and $+0.045 \mathrm{~mm}$ were over $87 \%$ and $93 \%$, respectively. In other words, fine size particles below $0.075 \mathrm{~mm}$ and $0.045 \mathrm{~mm}$ were less than $13 \%$ and $8 \%$ in weight, respectively.

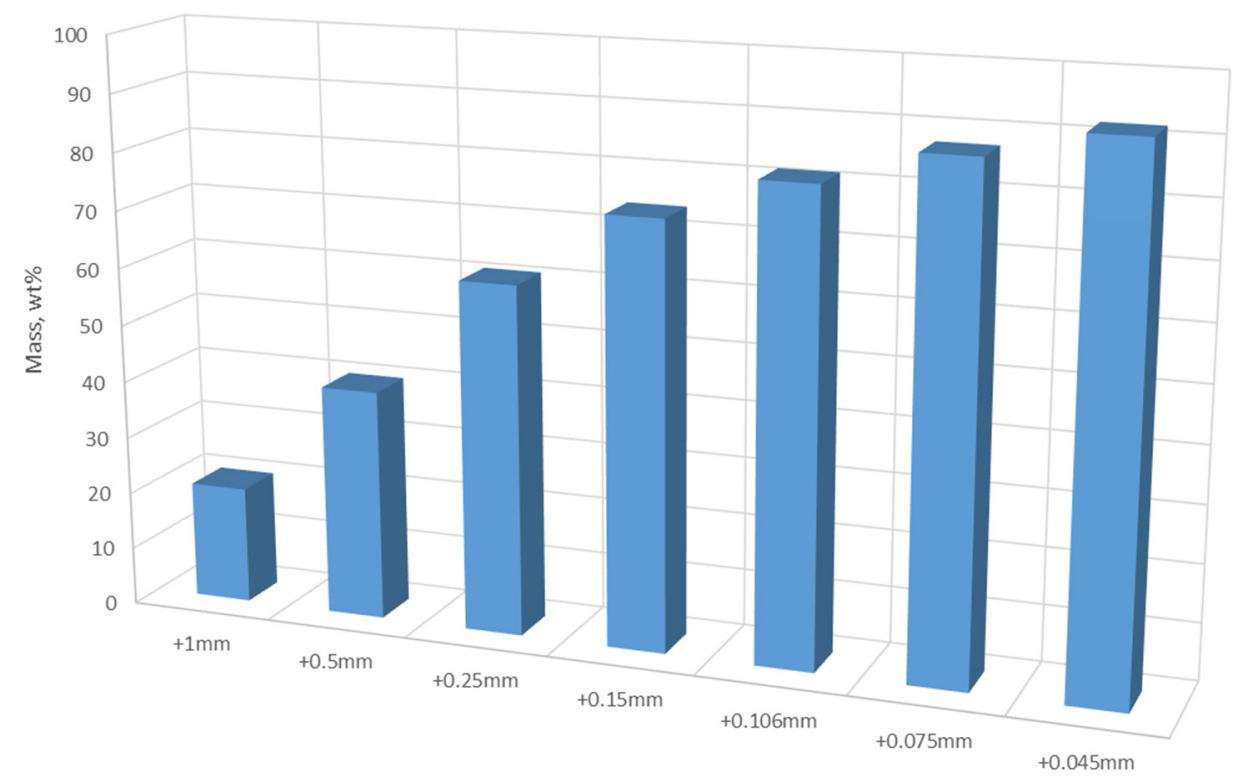

Figure 1. Particle size distribution. 


\subsubsection{Distributions of Elemental Contents in Size Fractions}

The BM material was classified according to size by sieving and all the fractions were analysed by XRF and Leco C. The analysis results showed that $\mathrm{Al}, \mathrm{Cu}, \mathrm{Ni}, \mathrm{Co}, \mathrm{Mn}$ and $\mathrm{C}$ are the main elements in the sample with significant contents. The contents of the elements $\mathrm{Al}, \mathrm{Cu}, \mathrm{Ni}, \mathrm{Co}, \mathrm{Mn}$ and $\mathrm{C}$ in all the fractions are presented in Figure 2 ( $\mathrm{Li}$ was also one of main elements measured by ICP-MS with an overall content of around 3.1\%). It is seen that the contents of $\mathrm{Cu}(3.8-17.5 \%)$ and $\mathrm{Al}(9.2-30.3 \%)$ are obviously higher in the coarser fractions $(+0.25 \mathrm{~mm})$ and the contents of $\mathrm{Ni}, \mathrm{Co}$ and $\mathrm{Mn}$ appear higher in the finer fractions $(-0.25 \mathrm{~mm})$. However, $\mathrm{C}$ with the contents of $32.8-41.0 \%$ distributes quite evenly in all the factions.

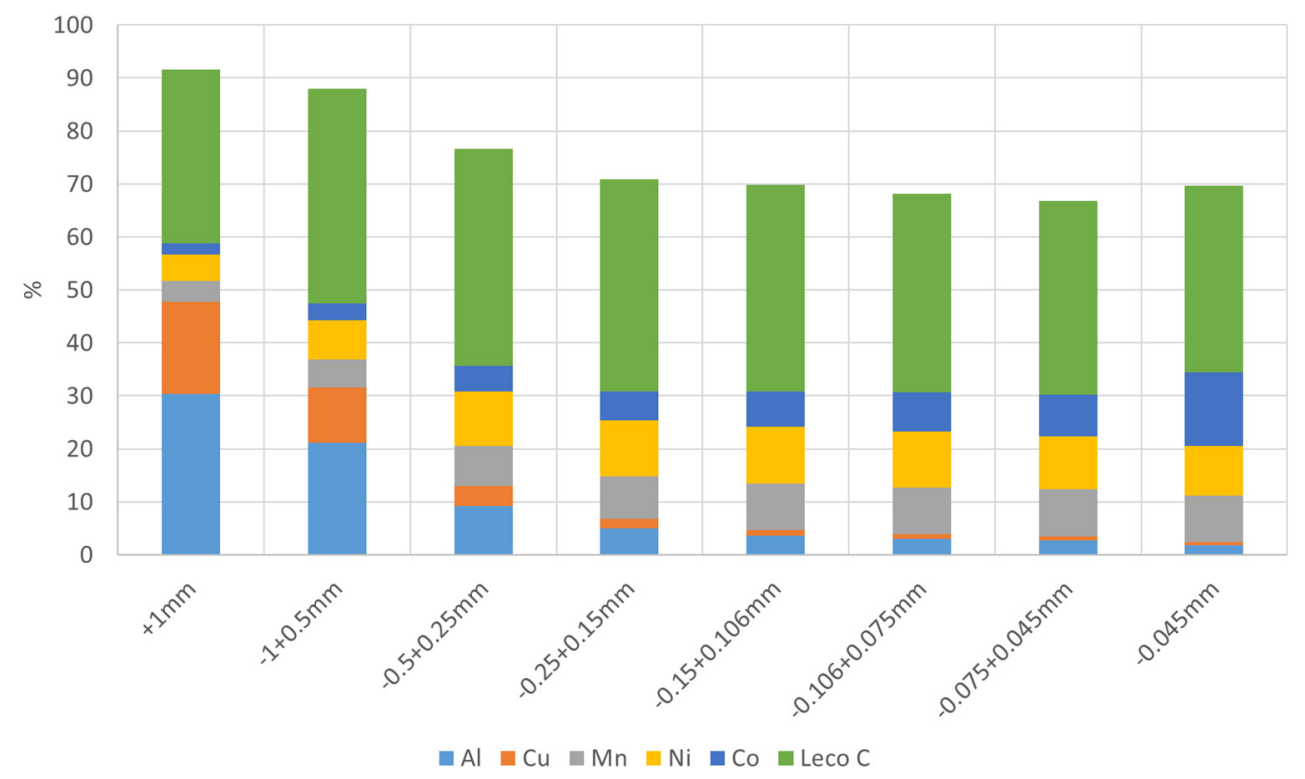

Figure 2. Distributions of elemental contents in size fractions.

\subsection{Mineralogical Analysis}

Graphite and the cathode active materials ( $\mathrm{Li})$-Co-oxide $\left(\mathrm{LiCoO}_{2},\right),(\mathrm{Li})-\mathrm{Mn}-\mathrm{Ni}-\mathrm{Co}-$ oxide ( $\mathrm{LiNixMnyCozO} \mathrm{O}_{2}$ ), and ( $\left.\mathrm{Li}\right)$-Ni-oxide $\left(\mathrm{LiNi}_{0.8} \mathrm{Co}_{0.2} \mathrm{O}_{2}\right)$ were identified by MLA as major phases in the studied samples. The theoretical chemical formulas and densities for the metal-oxides were adopted from the internet (www.americanelements.com (accessed on 22 October 2021)). The metal oxides are abbreviated as (Li)-compounds because $\mathrm{Li}$ cannot be detected by the EDS analyses due to its small atomic number $(\mathrm{Z}=3))$. The contents of graphite, the Li-containing metal oxides and other phases with significant amounts determined in the two fractions are shown in Table 1. It is seen that the compositions of the material are very complex. However, graphite and the four Li-containing metal oxides take up $92-94 \%$ of the amount. 
Table 1. The contents of the Li-containing metal oxides and graphite in the fractions of $-0.25+$ $0.106 \mathrm{~mm}$ and $-0.106 \mathrm{~mm}$ (wt.\%).

\begin{tabular}{ccc}
\hline Mineral & $\mathbf{- 0 . 2 5} \mathbf{+ 0 . 1 0 6 ~} \mathbf{~ m m}$ & $\mathbf{0 . 1 0 6 ~} \mathbf{~ m m}$ \\
\hline Graphite & 19.5 & $\mathbf{2 8 . 5}$ \\
(Li)-Co-oxide & 49.0 & 39.0 \\
(Li)-Mn-Ni-Co-oxide & 14.1 & 13.8 \\
(Li)-Ni-oxide & 7.3 & 8.8 \\
Mn-oxide & 2.0 & 4.2 \\
Al-oxide & 2.5 & 1.8 \\
Si-oxide & 2.6 & 0.7 \\
Ca-Al-silicate & 0.2 & 0.7 \\
Fe-oxide & 0.6 & 0.8 \\
Metal Cu * & 0.5 & - \\
Metal Al * & 0.2 & 0.1 \\
Metal Fe & 0.4 & - \\
Biotite & 0.8 & 0.1 \\
\hline
\end{tabular}

${ }^{*}$ Metals $\mathrm{Cu}$ and $\mathrm{Al}$ in the foils used as current collectors mostly exist in the coarse fractions $(+0.25 \mathrm{~mm})$.

\subsection{Classification by Sieving}

The sample was classified by sieving with aperture sizes of $1.0 \mathrm{~mm}, 0.5 \mathrm{~mm}, 0.25 \mathrm{~mm}$, $0.15 \mathrm{~mm}, 0.106 \mathrm{~mm}, 0.075 \mathrm{~mm}$ and $0.045 \mathrm{~mm}$. The relationships between the recoveries of main elements $\mathrm{Cu}, \mathrm{Ni}, \mathrm{Co}, \mathrm{Al}, \mathrm{Mn}$ and $\mathrm{C}$ in the oversize fractions and the mass yields (wt.\%) are shown in Figure 3. It is indicated that the metals $\mathrm{Cu}$ and $\mathrm{Al}$ display obvious separation in the oversize fractions, that is, in the $+1.0 \mathrm{~mm},+0.5 \mathrm{~mm}$ and $+0.25 \mathrm{~mm}$ fractions (related mass yields 20.4, 40.3 and $61.0 \mathrm{wt} . \%$ ) the recoveries of $\mathrm{Cu}$ reach $51.9 \%, 82.0 \%$ and $93.4 \%$, respectively, and those of $\mathrm{Al}$ reach $45.3 \%, 76.0 \%$ and $90.0 \%$, respectively.

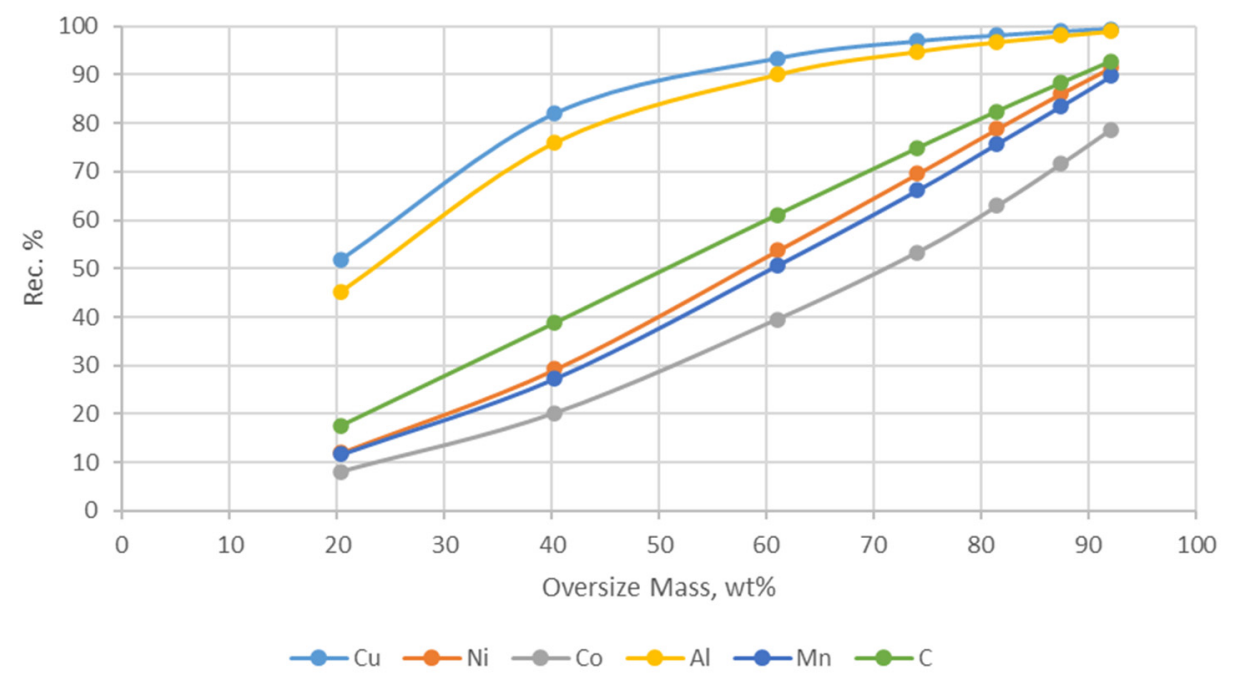

Figure 3. Recoveries of $\mathrm{Cu}, \mathrm{Ni}, \mathrm{Co}, \mathrm{Al}, \mathrm{Mn}$, and $\mathrm{C}$ in the oversize fractions vs. mass yields.

\subsection{Flotation}

The grades and recoveries of the main elements $\mathrm{C}, \mathrm{Cu}, \mathrm{Ni}, \mathrm{Co}, \mathrm{Mn}$, and $\mathrm{Al}$ in flotation concentrates for the coarse fraction $+0.25 \mathrm{~mm}$ for no roasting and being roasted at a temperature $350{ }^{\circ} \mathrm{C}$ prior to flotation are shown in Figure 4. It is seen that no significant difference was found in flotation result between with and without roasting. Roasting only slightly hindered the flotation of graphite and Li metal oxides. Generally, for both cases with and without roasting graphite (indicated by $\mathrm{C}$ ) and Li metal oxides (indicated by $\mathrm{Ni}$, $\mathrm{Co}, \mathrm{Mn}$ ) were well floated with relatively high recoveries $(85-95 \%$ for $\mathrm{C}$, and $77-85 \%$ for $\mathrm{Ni}$, $\mathrm{Co}$ and $\mathrm{Mn}$ ). However, mainly $\mathrm{Cu}$ and $\mathrm{Al}$ foils were sunk in the tailings, e.g., only $15-18 \%$ of $\mathrm{Cu}$ was entrained into the concentrate. 
The effects of roasting at different temperatures on the grades and recoveries of the main elements $\mathrm{C}, \mathrm{Cu}, \mathrm{Ni}, \mathrm{Co}, \mathrm{Mn}$ and $\mathrm{Al}$ in the flotation concentrates for the fine fraction $-0.25 \mathrm{~mm}$ are shown in Figure 5. The results indicate that roasting obviously improved the selectivity between the graphite and metallic elements $\mathrm{Ni}, \mathrm{Co}, \mathrm{Mn}, \mathrm{Cu}$ and $\mathrm{Al}$ on flotation; that is, significantly lower recoveries of the metallic elements were obtained in the concentrates after roasting than no roasting treatment. Meanwhile, roasting temperature affects the flotation performances of both graphite and metals. At the lower temperatures of $350{ }^{\circ} \mathrm{C}$ and $400{ }^{\circ} \mathrm{C}$, graphite still has almost the same high recoveries (>93\%) as no roasting treatment, but when the roasting temperature increased to $450{ }^{\circ} \mathrm{C}$, the flotation of both graphite and metallic matters were hindered. The recovery of graphite decreased to $50 \%$, although there was still obvious difference between graphite and the metallic elements on recovery. Based on the results, the optimal temperature of roasting for graphite flotation is $400{ }^{\circ} \mathrm{C}$.

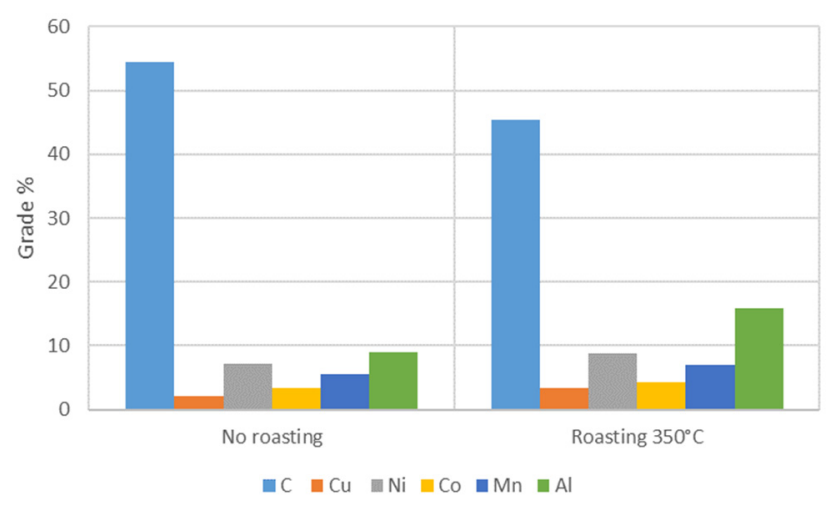

(a)

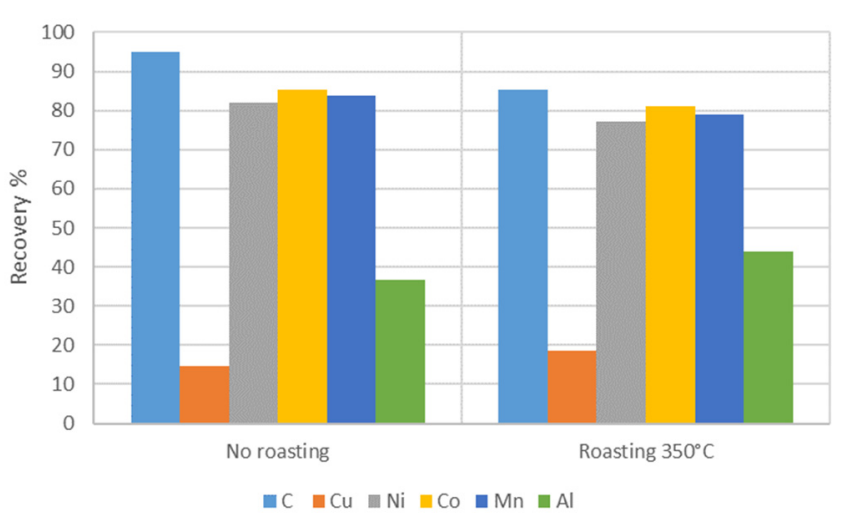

(b)

Figure 4. Effects of roasting on grade (a) and recovery (b) of main components in the flotation concentrate for $+0.25 \mathrm{~mm}$ fraction.

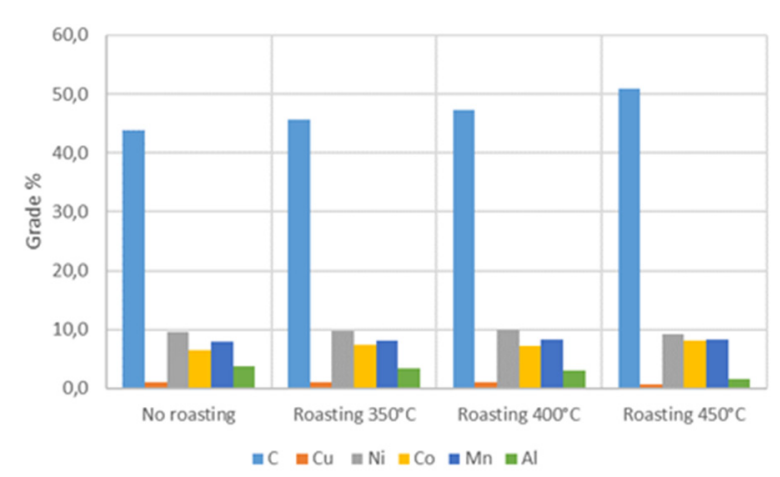

(a)

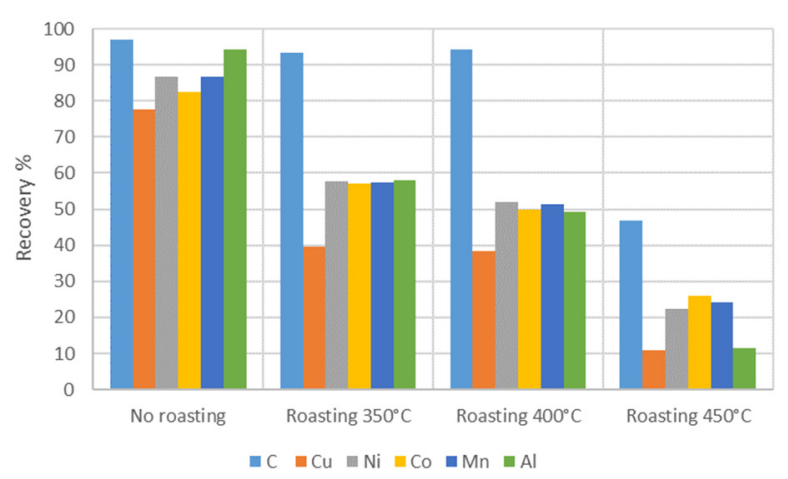

(b)

Figure 5. Effects of roasting on grade (a) and recovery (b) of main components in the flotation concentrate for $-0.25 \mathrm{~mm}$ fraction.

\section{Discussion}

The study showed that the metals $\mathrm{Cu}$ and $\mathrm{Al}$ can be effectively separated by simple sieving and flotation operations at a coarse size $(+0.25 \mathrm{~mm})$. However, the separation of graphite from the cathode active metals $\mathrm{Co}, \mathrm{Ni}$ and $\mathrm{Mn}$ was challenging. Further processing, including finely grinding, followed by roasting and flotation, could improve their separation. For the fine fraction $(-0.25 \mathrm{~mm})$ by flotation after roasting at a temperature of $350-450{ }^{\circ} \mathrm{C}$ for $30 \mathrm{~min}$ over $90 \%$ of graphite was recovered, but significant amounts (about $50 \%$ ) of $\mathrm{Co}, \mathrm{Ni}$ and $\mathrm{Mn}$ were floated into the graphite concentrate. This is mainly attributed to very fine particle sizes $(\sim 10 \mu \mathrm{m})$ of graphite and Li metal oxides and their very 
tight association, as shown in the back-scattered electron image (Figure 6). Meanwhile, the coatings of the organic binders on the surfaces of graphite and the Li metal oxides might be very difficult to completely remove during roasting. Roasting at a higher temperature than $450{ }^{\circ} \mathrm{C}$ might cause significant surface oxidation of both graphite and metallic matters which hinders their flotation.

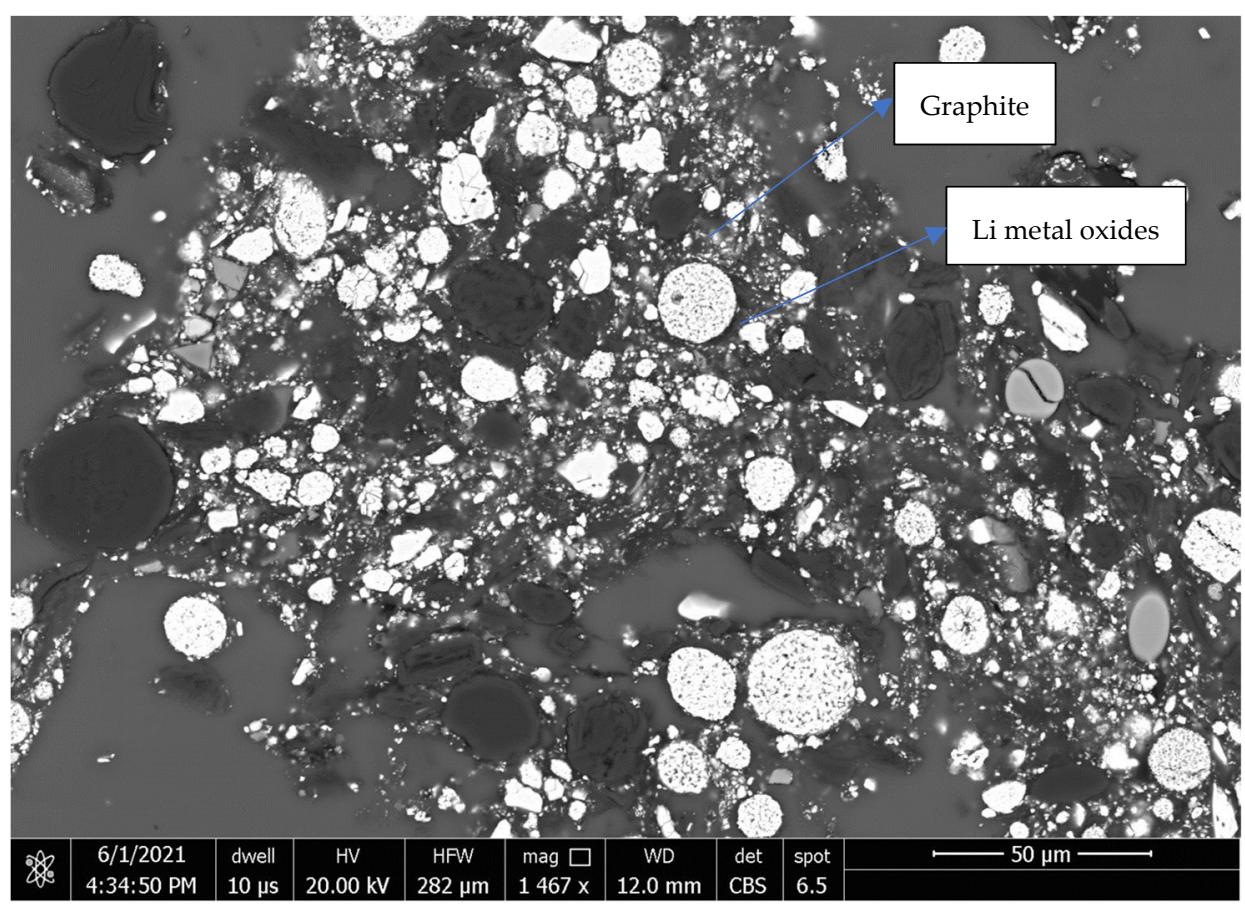

Figure 6. Back-scattered electron image of the fine fraction $-0.25 \mathrm{~mm}$.

\section{Conclusions}

The main elements of recycled LIBs include $\mathrm{Li}, \mathrm{Al}, \mathrm{Cu}, \mathrm{Ni}, \mathrm{Co}, \mathrm{Mn}$ and $\mathrm{C}$ with significant contents. The contents of $\mathrm{Cu}$ and $\mathrm{Al}$ were obviously higher in the coarser fractions $(+0.25 \mathrm{~mm})$ and $\mathrm{Ni}, \mathrm{Co}$ and $\mathrm{Mn}$ appear in content higher in the finer fractions $(-0.25 \mathrm{~mm})$. However, $\mathrm{C}$ with content of $32.8-41.0 \%$ distributes quite evenly in all the sieve factions.

The BM has very complex compositions, but graphite and the cathode active materials (Li)-Co-oxide, (Li)-Mn-Ni-Co-oxide, and ( $\mathrm{Li}$ )-Ni-oxide were identified to be the major components in the fraction of $-0.25 \mathrm{~mm}$, taking up $92-94 \%$ of the amount. Metals $\mathrm{Cu}$ and $\mathrm{Al}$ in the foils used as current collectors mostly exist in the coarse fractions $(+0.25 \mathrm{~mm})$.

Through sieving the BM material into $+0.25 \mathrm{~mm}$ and $-0.25 \mathrm{~mm}$ fractions, the metals $\mathrm{Cu}$ and $\mathrm{Al}$ were mostly $(>90 \%)$ concentrated in the oversize fraction of $+0.25 \mathrm{~mm}$, from which $\mathrm{Cu}$ and $\mathrm{Al}$ were further separated by flotation from graphite and the cathode active materials.

For the undersize fraction of $-0.25 \mathrm{~mm}$, roasting at a temperature of $350-450{ }^{\circ} \mathrm{C}$ for $30 \mathrm{~min}$ as pre-treatment obviously improved the selectivity between graphite and the metals $\mathrm{Ni}, \mathrm{Co}, \mathrm{Mn}, \mathrm{Cu}$ and $\mathrm{Al}$ by flotation, that is, significantly lower recoveries of the metals were obtained in the concentrates after roasting than no roasting treatment.

Author Contributions: X.Y., investigation, original draft preparation and editing; A.T. and K.K., material characterization and reviewing. All authors have read and agreed to the published version of the manuscript.

Funding: This research was funded by BUSINESS FINLAND, grant number 6814/31/2019.

Institutional Review Board Statement: Not applicable.

Informed Consent Statement: Not applicable. 
Acknowledgments: The authors are grateful to ERA-MIN2 programme and project NEXT-LIB. Thanks to Guozhu Ye and Elsayed Mousa Mourad (Swerim AB), and Bruno Renato Valério Valentim (University of Porto) for helpful discussions and providing some analysis data in the project.

Conflicts of Interest: The authors declare no conflict of interest.

\section{References}

1. Available online: https://www.fnfresearch.com/global-lithium-ion-battery-market-by-type-lithium-795 (accessed on 22 October 2021).

2. Velázquez-Martínez, O.; Valio, J.; Santasalo-Aarnio, A.; Reuter, M.; Serna-Guerrero, R. A Critical Review of Lithium-Ion Battery Recycling Processes from a Circular Economy Perspective. Batteries 2019, 5, 68. [CrossRef]

3. Larouche, F.; Tedjar, F.; Amouzegar, K.; Houlachi, G.; Bouchard, P.; Demopoulos, G.P.; Karim, Z. Progress and Status of Hydrometallurgical and Direct Recycling of Li-Ion Batteries and Beyond. Materials 2020, 13, 801. [CrossRef] [PubMed]

4. Wang, F.; Zhang, T.; He, Y.; Zhao, Y.; Wang, S.; Zhang, G.; Zhang, Y.; Feng, Y. Recovery of valuable materials from spent lithium-ion batteries by mechanical separation and thermal treatment. J. Clean. Prod. 2018, 185, 646-652. [CrossRef]

5. He, Y.; Zhang, T.; Wang, F.; Zhang, G.; Zhang, W.; Wang, J. Recovery of $\mathrm{LiCoO}_{2}$ and graphite from spent lithium-ion batteries by Fenton reagent-assisted flotation. J. Clean. Prod. 2017, 143, 319-325. [CrossRef]

6. Zhang, G.; He, Y.; Wang, H.; Feng, Y.; Xie, W.; Zhu, X. Application mechanical crushing combined with pyrolysis enhanced flotation technology to recover graphite and LiCoO2 from spent lithium-ion batteries. J. Clean. Prod. 2019, 231, 1418-1427. [CrossRef]

7. Sloop, S.; Crandon, L.; Allen, M.; Koetje, K.; Reed, L.; Gaines, L.; Sirisaksoontorn, W.; Lerner, M. A direct recycling case study from a lithium-ion battery recall. Sustain. Mater. Technol. 2020, 25, e00152. [CrossRef]

8. Vanderbrugge, A.; Rudolph, M. Flotation of Spherodized Graphite from Spent Lithium Ion Batteries. Available online: https: //www.researchgate.net/publication/338832842 (accessed on 22 October 2021). 